[Regular Paper]

\title{
Adsorptive Removal of $t$-Butanethiol Using Metal lon-exchange Y Type Zeolite under Ambient Conditions
}

\author{
Shigeo SATOKAWA*, Takuro OHNUKI, Tomoki TAKAhIRO, Kohei URASAKI, and Toshinori KoJIMA \\ Dept. of Materials and Life Science, Faculty of Science and Technology, Seikei University, \\ 3-3-1 Kichijoji-kitamachi, Musashino, Tokyo 180-8633, JAPAN
}

(Received September 7, 2009)

\begin{abstract}
Adsorptive removal of $t$-butanethiol (TBT), an odorant additive, from city gas was carried out using metal ionexchange $\mathrm{Y}$ type zeolites at ambient temperature and pressure. The adsorption capacity of TBT on Na-Y under the wet gas condition was extremely low, although that under the dry gas condition was certainly higher. The adsorption capacity of TBT on silver ion-exchange $\mathrm{Y}$ type zeolites $(\mathrm{Ag}(\mathrm{Na})-\mathrm{Y})$ increased with higher silver ionexchange ratio in $\mathrm{Ag}(\mathrm{Na})-\mathrm{Y}$ under wet gas condition. In contrast, the adsorption capacity of TBT on $\mathrm{Ag}(\mathrm{Na})-\mathrm{Y}$ under the dry gas condition decreased with higher silver ion-exchange ratio in $\mathrm{Ag}(\mathrm{Na})-\mathrm{Y}$. Formation of silver sulfide clusters in $\operatorname{Ag}(\mathrm{Na})-\mathrm{Y}$ causes the decrease in sulfur adsorption capacity of it under the dry gas condition. The adsorption capacity of TBT on copper ion-exchange $\mathrm{Y}$ type zeolites $(\mathrm{Cu}(\mathrm{Na})-\mathrm{Y})$ increased with higher copper ion-exchange ratio in $\mathrm{Cu}(\mathrm{Na})-\mathrm{Y}$ under the wet gas condition. In the case of $\mathrm{Cu}(\mathrm{Na})-\mathrm{Y}$, the decrease of TBT adsorption capacity under the dry gas condition did not occur with higher copper ion-exchange ratio in $\mathrm{Cu}(\mathrm{Na})-\mathrm{Y}$. The both spent samples of $\mathrm{Ag}(\mathrm{Na})-\mathrm{Y}$ and $\mathrm{Cu}(\mathrm{Na})-\mathrm{Y}$ were regenerated by heat treatment in air. The decrease in adsorption capacity of TBT on $\mathrm{Cu}(\mathrm{Na})-\mathrm{Y}$ was slightly lower than that on $\mathrm{Ag}(\mathrm{Na})-\mathrm{Y}$.
\end{abstract}

\section{Keywords}

Adsorptive removal, $t$-Butanethiol, Y type zeolite, Silver ion exchange, Copper ion exchange,

Ambient adsorption

\section{Introduction}

Development of the polymer electrolyte fuel cell (PEFC) as a primary generator for stationary and mobile source applications is one of the most promising ways to increase the efficiency of energy utilization. City gas is one of the most useful energy sources for the stationary applications because of the existing pipeline supply networks. The composition of city gas varies by region and localityl). A few ppm of sulfurcontaining odorant, such as dimethylsulfide (DMS) and/or $t$-butanethiol (TBT), is generally added to city gas in order to give people warning of gas leakage in Japan. However, these sulfur compounds are extremely poisonous for steam reforming catalysts, so the city gas requires deep desulfurization before introduction to the reforming process for PEFC applications ${ }^{2}$. Current hydrodesulfurization (HDS) processes, involving catalytic hydrogen treatment to remove organosulfur compounds such as hydrogen sulfide $\left(\mathrm{H}_{2} \mathrm{~S}\right)$, combined with subsequent adsorption of $\mathrm{H}_{2} \mathrm{~S}$ on zinc oxide, operate at elevated temperatures $\left(>300^{\circ} \mathrm{C}\right)$ and pressures $(20$ to

\footnotetext{
* To whom correspondence should be addressed.

*E-mail: satokawa@st.seikei.ac.jp
}

100 atm of hydrogen) $)^{3}$. Consequently, such HDS processes are difficult to apply to residential PEFC systems, which require quick and easy start-up, simple operation, and small reactor size. Therefore, a new desulfurization process for PEFC system has been developed based on the adsorption of sulfur compounds under ambient conditions.

Activated carbon and manganese dioxide were first proposed as materials for the desulfurization of pipeline natural gas at ambient temperatures ${ }^{4}$, but the sulfur adsorption capacities were inadequate for practical use. DMS and TBT were removed from city gas by using $\mathrm{Na}^{+}$and $\mathrm{H}^{+}$exchange zeolites at ambient temperature $^{5}$. However, the zeolites had significantly low sulfur capacity in the presence of $1000 \mathrm{ppm}$ water ${ }^{6}$. Generally, little water vapor is contained in a city gas produced from liquefied natural gas (LNG). However, the city gas may be contaminated by a few hundred ppm of water vapor during the pipeline distribution from the gas production facility to the customer. Recently, silver ion exchange zeolites, especially $\mathrm{Ag}(\mathrm{Na})-\mathrm{Y}$ zeolites, were reported as favorable adsorbents with high capacity and low leakage for desulfurization of city gas at ambient conditions even in the presence of water vapor ${ }^{(6), 7)}$. Silver ion exchange 
zeolites are also effective for removing sulfur compounds such as $\mathrm{DMS}^{8)}$, tetrahydrothiophene $\mathrm{e}^{9)}$ and thiophenes ${ }^{10) \sim 14)}$.

The color change of $\mathrm{Ag}(\mathrm{Na})-\mathrm{Y}$ from white to yellow during TBT adsorption suggests the formation of silver sulfide clusters via $\mathrm{C}-\mathrm{S}$ bond cleavage of TBT adsorbed on silver ion and subsequent $\mathrm{Ag}-\mathrm{S}$ bond formation ${ }^{7)}$. The presence of silver sulfides ( $\mathrm{AgSH}, \mathrm{Ag}_{2} \mathrm{~S}$ monomer and $\mathrm{Ag}_{4} \mathrm{~S}_{2}$ cluster) in TBT-saturated $\mathrm{Ag}(\mathrm{Na})-\mathrm{Y}$ samples was demonstrated by a combination of X-ray diffraction (XRD), Ag K-edge X-ray absorption near-edge structure (XANES) and extended X-ray absorption fine structures (EXAFS) methods ${ }^{15}$.

Recently, the concentration of sulfur compounds in city gas has been lowered because of the reduction in reactor volume for the reforming processes. Interestingly, the sulfur adsorption capacity of $\mathrm{Ag}(\mathrm{Na})^{-}$ $\mathrm{Y}$ zeolite for a gas stream containing a single component (only TBT) was lower than for a gas stream containing two sulfur components (TBT and DMS $)^{7)}$. Therefore, TBT adsorption capacity of $\mathrm{Ag}(\mathrm{Na})-\mathrm{Y}$ zeolite was re-evaluated under wet and dry gas conditions. The adsorption capacity of TBT of other metal ionexchange $\mathrm{Y}$ type zeolites was also investigated.

\section{Experimental}

\section{1. Preparation of Adsorbents}

$\mathrm{Na}^{-} \mathrm{Y}$ type zeolite (JRC-Z-Y 5.5, a reference catalyst of the Catalysis Society of Japan, $\mathrm{SiO}_{2} / \mathrm{Al}_{2} \mathrm{O}_{3}=5.5$, surface area $=870 \mathrm{~m}^{2} \cdot \mathrm{g}^{-1}$ ) was used to prepare silver, copper and zinc ion exchange zeolites by the conventional ion exchange method treating the $\mathrm{Na}-\mathrm{Y}$ zeolite with aqueous solutions of silver nitrate, copper acetate and zinc nitrate at $298 \mathrm{~K}$ for $6 \mathrm{~h}$, respectively. After the ion exchange treatment, solid products were obtained by filtration, washing with water and subsequent air drying at $373 \mathrm{~K}$ for $12 \mathrm{~h}$. Ion exchange ratios of metal ions were determined by elemental analysis using inductively coupled plasma atomic emission spectroscopy (Shimadzu, ICPS-7500). All samples were crushed, sieved to obtain particle sizes between 0.2 and $0.4 \mathrm{~mm}$ in diameter and heat-treated at $673 \mathrm{~K}$ in air. The ion exchange ratio was calculated from the molar ratio of $\mathrm{Ag}^{+}, \mathrm{Cu}^{2+}$ or $\mathrm{Zn}^{2+}$ ion and the cation exchange capacity of $\mathrm{Na}-\mathrm{Y}$. The sample name, e.g., $\mathrm{Ag}(\mathrm{Na})-\mathrm{Y}(19)$, indicates that the silver ion exchange ratio of this sample is $19 \%$.

\section{2. Adsorption Tests and Regeneration Methods}

Adsorption experiments were carried out using a fixed-bed flow tubular reactor ( $3 \mathrm{~mm}$ inner diameter). $20 \mathrm{ppm}$ of TBT in nitrogen was fed to $0.1 \mathrm{~g}$ of adsorbents at room temperature $(298 \mathrm{~K})$ without pretreatment. The gas flow rate was $500 \mathrm{~cm}^{3} \cdot \mathrm{min}^{-1}$ and the GHSV was about $180,000 \mathrm{~h}^{-1}$. TBT concentration in the reactor effluent was measured by gas chromatogra- phy with a flame photometric detector (Shimadzu GC14B with flame photometric detector). Water concentration of the reaction gas was less than $10 \mathrm{ppm}$ (dry gas condition) and was also adjusted to $1000 \mathrm{ppm}$ by passing part of the nitrogen flow through water (wet gas condition). The sulfur adsorption capacity was determined by the breakthrough capacity, i.e., uptake amount of sulfur at the moment of first detection of TBT (about $0.1 \mathrm{ppm}$ ) in the outlet gas. The used adsorbents were regenerated by heat-treatment at $673 \mathrm{~K}$ for $2 \mathrm{~h}$ in air. The regenerated adsorbent was cooled to room temperature in nitrogen and used to re-evaluate the TBT adsorption capacity.

\section{3. Surface Analysis}

In-situ Fourier transform infrared spectroscopy (FTIR) spectra were recorded using a Shimadzu FTIR 8300 equipped with the transmitting IR cell connected to a conventional flow reaction system. A sample was pressed into a $0.02 \mathrm{~g}$ self supporting wafer and mounted into a quartz IR cell with $\mathrm{CaF}_{2}$ windows. The sample was heated at $473 \mathrm{~K}$ for $2 \mathrm{~h}$ and cooled to $298 \mathrm{~K}$ in the IR cell under a nitrogen flow. Spectra were measured with resolution of $4 \mathrm{~cm}^{-1}$ at $298 \mathrm{~K}$ and each spectrum consisted of 32 scans. A reference spectrum of the sample was recorded at $298 \mathrm{~K}$ in the IR cell purged by nitrogen flow for $30 \mathrm{~min}$ and used as the background spectrum. Reaction gas (100 ppm TBT diluted by nitrogen) was introduced onto the samples and the gas flow rate was controlled at $500 \mathrm{~cm}^{3} \cdot \mathrm{min}^{-1}$. The temperature was controlled by an electric heater with a thermocouple attached near the sample wafer. The spectrum of the sample was recorded at $298 \mathrm{~K}$ after the IR cell was purged with nitrogen for $30 \mathrm{~min}$. In-situ FTIR spectra of adsorbed species were obtained by subtraction of the background spectrum from the sample spectra.

\section{Results and Discussion}

\section{1. Characterization of Samples}

The XRD patterns of ion-exchange samples were almost the same as the XRD pattern of raw material $(\mathrm{Na}-\mathrm{Y})$. No peaks due to metals and metal oxides except $Y$ type zeolite were observed in the XRD patterns of all samples. $\mathrm{Ag}(\mathrm{Na})^{-} \mathrm{Y}$ and $\mathrm{Zn}(\mathrm{Na})^{-} \mathrm{Y}$ were white like $\mathrm{Na}-\mathrm{Y}$ and $\mathrm{Cu}(\mathrm{Na})-\mathrm{Y}$ was light blue, suggesting that the ionic states of silver, copper and zinc ions in $\mathrm{Ag}(\mathrm{Na})-\mathrm{Y}, \mathrm{Cu}(\mathrm{Na})-\mathrm{Y}$ and $\mathrm{Zn}(\mathrm{Na})-\mathrm{Y}$ are $\mathrm{Ag}^{+}$, $\mathrm{Cu}^{2+}$ and $\mathrm{Zn}^{2+}$, respectively.

\section{2. TBT Adsorption on $\mathrm{Ag}(\mathrm{Na})-\mathrm{Y}$}

Figure 1 shows the effects of the silver ion-exchange ratio of $\mathrm{Ag}(\mathrm{Na})-\mathrm{Y}$ on the removal of TBT under dry and wet conditions. The adsorption capacity of TBT on $\mathrm{Na}^{-} \mathrm{Y}$ was certainly high under the dry gas condition. However, the adsorption capacity on $\mathrm{Na}^{-} \mathrm{Y}$ under the wet gas condition was extremely low. Strong 


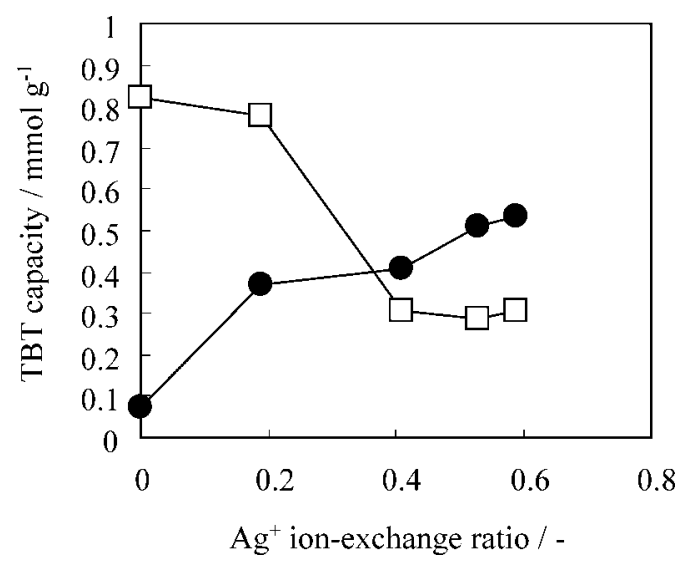

Feed: 20 ppm TBT in nitrogen with $(\mathbf{O})$ or without $(\square) 1000$ ppm of water vapor.

Fig. 1 Effect of Silver Ion-exchange Ratio in $\mathrm{Ag}(\mathrm{Na})-\mathrm{Y}$ Zeolite on TBT Adsorption Capacity

interactions between water molecules and sodium ions in $\mathrm{Na}-\mathrm{Y}$ probably caused the inhibition of TBT adsorption on $\mathrm{Na}-\mathrm{Y}$ under the wet gas condition.

The TBT adsorption capacities on $\operatorname{Ag}(\mathrm{Na})-\mathrm{Y}$ increased with higher silver ion-exchange ratio of $\mathrm{Ag}(\mathrm{Na})-\mathrm{Y}$ under the wet gas condition. The increase of TBT adsorption capacities on $\mathrm{Ag}(\mathrm{Na})-\mathrm{Y}$ under the wet gas condition results from the interaction between silver ions in $\mathrm{Ag}(\mathrm{Na})-\mathrm{Y}$ and TBT molecules. In contrast, the adsorption capacity of TBT on $\mathrm{Ag}(\mathrm{Na})-\mathrm{Y}$ under the dry gas condition decreased with higher silver ion-exchange ratio of $\mathrm{Ag}(\mathrm{Na})-\mathrm{Y}$.

Color change of $\operatorname{Ag}(\mathrm{Na})-\mathrm{Y}$ was observed after adsorption experiments under the dry gas condition. The color of $\mathrm{Ag}(\mathrm{Na})-\mathrm{Y}$ changed from white to yellow in the case of low silver ion content in $\mathrm{Ag}(\mathrm{Na})-\mathrm{Y}$ and changed from white to brown in the case of relatively high silver ion content in $\operatorname{Ag}(\mathrm{Na})-\mathrm{Y}$. On the other hand, no color change was observed for $\mathrm{Ag}(\mathrm{Na})-\mathrm{Y}$ after adsorption experiments under the wet gas condition. Therefore, some reactions except for adsorption between silver ions and TBT molecules occurred in $\mathrm{Ag}(\mathrm{Na})-\mathrm{Y}$ during adsorption experiments under the dry gas condition.

Figure 2 shows the change in S/Ag atomic ratio as defined by sulfur adsorption capacity at the TBT breakthrough time and silver content in $\mathrm{Ag}(\mathrm{Na})-\mathrm{Y}$. Significant decrease of the S/Ag atomic ratio occurred with higher silver ion-exchange ratio of $\mathrm{Ag}(\mathrm{Na})-\mathrm{Y}$ under both dry and wet gas conditions. AgSH molecule, $\mathrm{Ag}_{2} \mathrm{~S}$ monomer and $\mathrm{Ag}_{4} \mathrm{~S}_{2}$ cluster are the dominant silver species in TBT saturated $\mathrm{Ag}(\mathrm{Na})-\mathrm{Y}$ according to the previous mechanistic study on adsorptive removal of TBT on $\operatorname{Ag}(\mathrm{Na})-\mathrm{Y}^{15}$. Therefore, the amount of $\mathrm{Ag}_{4} \mathrm{~S}_{2}$ clusters probably increased with increased number of silver ions in $\mathrm{Ag}(\mathrm{Na})^{-} \mathrm{Y}$ and the formation of $\mathrm{Ag}_{4} \mathrm{~S}_{2}$

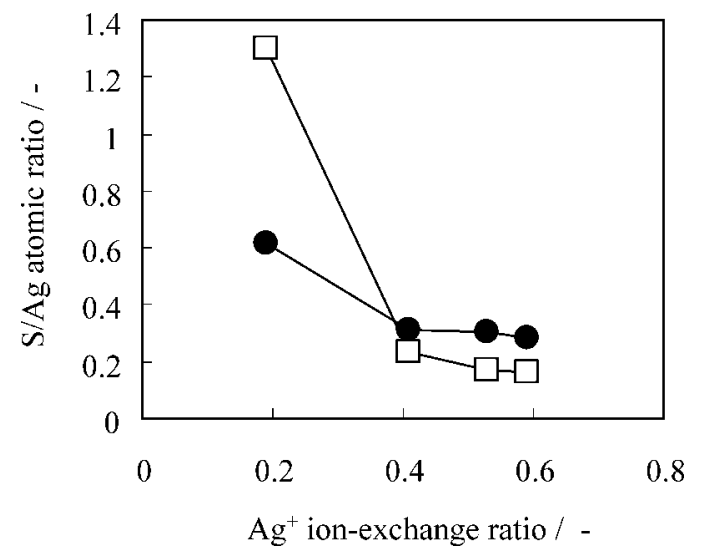

Fig. 2 Effect of Silver Ion-exchange Ratio in $\mathrm{Ag}(\mathrm{Na})-\mathrm{Y}$ Zeolite for S/Ag Atomic Ratio Defined by Sulfur Adsorption Capacity and Silver Content

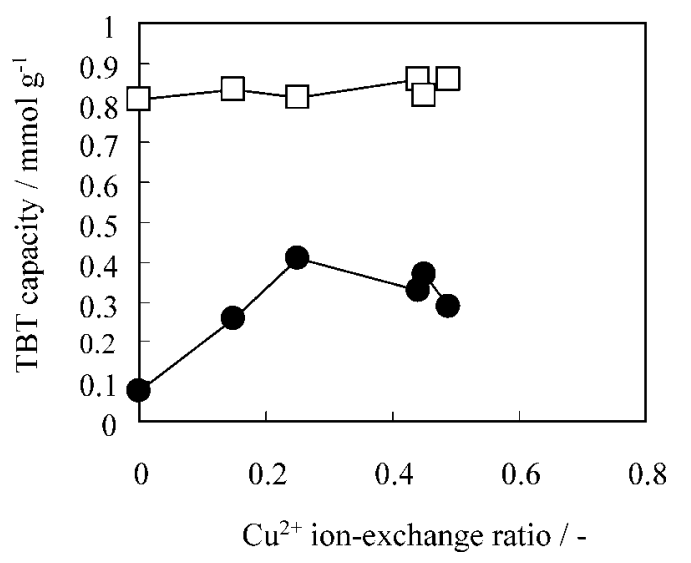

Feed: 20 ppm TBT in nitrogen with water vapor.

Fig. 3 Effect of Copper Ion-exchange Ratio in $\mathrm{Cu}(\mathrm{Na})-\mathrm{Y}$ Zeolite on TBT Adsorption Capacity

clusters caused a decrease in S/Ag value to 0.5 under both dry and wet gas conditions. The decrease in pore volume caused by the formation of large $\mathrm{Ag}_{4} \mathrm{~S}_{2}$ clusters occurred at around the breakthrough point ${ }^{15)}$. Further growth of $\mathrm{Ag}_{4} \mathrm{~S}_{2}$ cluster size under the dry gas condition causes further decrease of TBT adsorption capacity by hindrance of gas diffusion in the zeolite micropores resulting in the observed color changes ${ }^{16)}$.

3. 3. TBT Adsorption on $\mathrm{Cu}(\mathrm{Na})-\mathrm{Y}$ and $\mathrm{Zn}(\mathrm{Na})-\mathrm{Y}$

$\mathrm{Cu}(\mathrm{Na})-\mathrm{Y}$ changed from light blue to light green after the adsorption experiment. Color change was not observed for $\mathrm{Zn}(\mathrm{Na})^{-} \mathrm{Y}$. Figure 3 shows the effects of the copper ion-exchange ratio of $\mathrm{Cu}(\mathrm{Na})-\mathrm{Y}$ for removal of TBT under dry and wet gas conditions. The adsorption capacity of TBT on $\mathrm{Cu}(\mathrm{Na})-\mathrm{Y}$ under the wet gas condition was larger than that on $\mathrm{Na}-\mathrm{Y}$. The adsorption capacity of TBT on $\mathrm{Cu}(\mathrm{Na})-\mathrm{Y}(25)$ was $0.41 \mathrm{mmol} \cdot \mathrm{g}^{-1}$, and was the highest adsorption capacity 


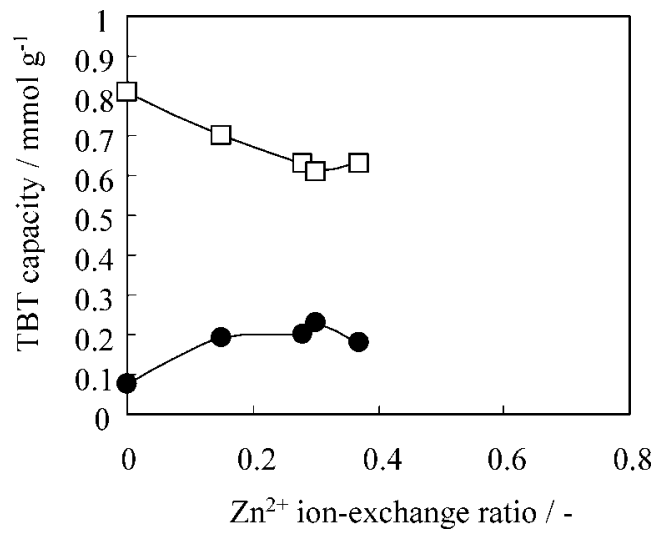

Feed: 20 ppm TBT in nitrogen with $(\mathbf{O})$ or without $(\square) 1000$ ppm of water vapor.

Fig. 4 Effect of Zinc Ion-exchange Ratio in $\mathrm{Zn}(\mathrm{Na})-\mathrm{Y}$ Zeolite on TBT Adsorption Capacity

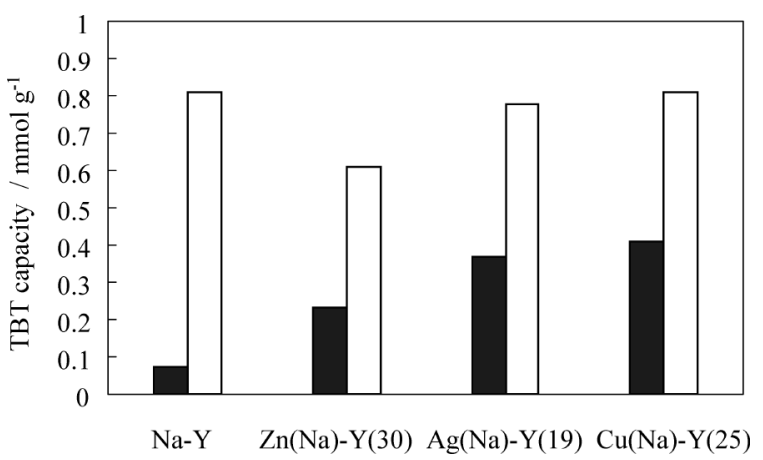

Fig. 5 Comparison of TBT Adsorption Capacities on Various Metal Exchanged Zeolites under Wet (solid line) and Dry (open line) Gas Conditions

of TBT under the wet gas condition for $\mathrm{Cu}(\mathrm{Na})-\mathrm{Y}$. The adsorption capacity of TBT on $\mathrm{Cu}(\mathrm{Na})-\mathrm{Y}$ under the dry gas condition was almost the same as that on $\mathrm{Na}^{-} \mathrm{Y}$. Decrease of adsorption capacity of TBT on $\mathrm{Cu}(\mathrm{Na})-\mathrm{Y}$ under the dry gas condition did not occur with higher copper ion-exchange ratio in $\mathrm{Cu}(\mathrm{Na})^{-} \mathrm{Y}$.

Figure 4 shows the effects of the zinc ion-exchange ratio of $\mathrm{Zn}(\mathrm{Na})-\mathrm{Y}$ for removal of TBT under dry and wet gas conditions. The adsorption capacities of $\mathrm{Zn}(\mathrm{Na})-\mathrm{Y}$ were slightly lower than those of $\mathrm{Cu}(\mathrm{Na})-\mathrm{Y}$ under both dry and wet gas conditions. Efficiencies of TBT removal by $\mathrm{Na}-\mathrm{Y}, \mathrm{Ag}(\mathrm{Na})-\mathrm{Y}(19), \mathrm{Cu}(\mathrm{Na})-\mathrm{Y}(25)$, and $\mathrm{Zn}(\mathrm{Na})-\mathrm{Y}(30)$ under dry and wet gas conditions are compared in Fig. 5. The highest sulfur adsorption capacities under both dry and wet gas conditions were achieved with $\mathrm{Cu}(\mathrm{Na})-\mathrm{Y}(25)$.

\section{4. Surface Analysis by In-situ FTIR}

In-situ FTIR spectrum of $\mathrm{Na}^{-} \mathrm{Y}$ after adsorption of TBT is shown in Fig. 6(a). The $\gamma(\mathrm{SH})$ band at $2560 \mathrm{~cm}^{-1}$ observed in the spectrum of $\mathrm{Na}^{-\mathrm{Y}}$ was assigned to physically adsorbed TBT. Bands at 1465,

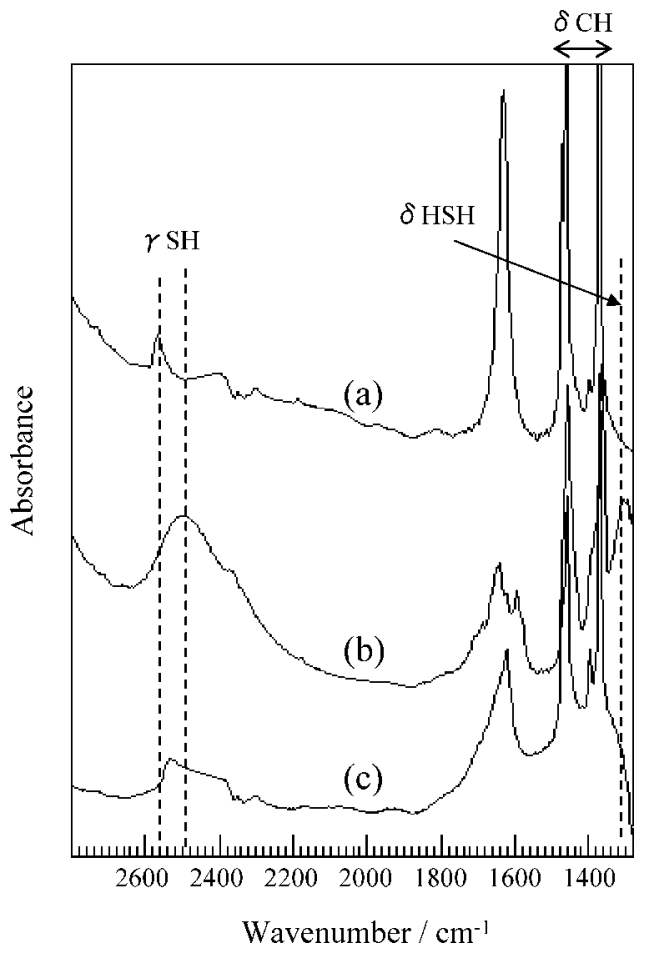

Fig. 6 In-situ IR Spectra of Adsorbed Species on (a) Na-Y, (b) $\mathrm{Ag}(\mathrm{Na})-\mathrm{Y}(19)$ and (c) $\mathrm{Cu}(\mathrm{Na})-\mathrm{Y}(25)$ after Contact with 100 ppm TBT in Nitrogen Flow for $30 \mathrm{~min}$, Followed by Purging with Nitrogen for $30 \mathrm{~min}$

1454,1370 and $1360 \mathrm{~cm}^{-1}$ due to the $\delta(\mathrm{CH})$ band of the $t$-butyl group of adsorbed TBT were observed in the $\mathrm{CH}$ deformation region for $\mathrm{Na}^{-} \mathrm{Y}$. Therefore, the TBT molecule is probably physically adsorbed onto $\mathrm{Na}^{-}$ $\mathrm{Y}^{5), 17)}$.

The spectrum of $\operatorname{Ag}(\mathrm{Na})-\mathrm{Y}(19)$ after adsorption of TBT is shown in Fig. 6(b). In contrast to the spectrum of $\mathrm{Na}^{-} \mathrm{Y}$, the $\gamma(\mathrm{SH})$ band shifted to lower wavenumber was observed in the spectrum of $\mathrm{Ag}(\mathrm{Na})-\mathrm{Y}(19)$. A broad absorption peak not seen in the spectrum of $\mathrm{Na}-\mathrm{Y}$ was observed at $1310 \mathrm{~cm}^{-1}$ which was assigned to the $\delta(\mathrm{HSH})$ band. On the basis of previous studies, a relatively sharp band centered around $1640-1650 \mathrm{~cm}^{-1}$ was assigned to adsorbed molecular $i$-butene ${ }^{18) \sim 20)}$. Broad bands at 2500 and $1310 \mathrm{~cm}^{-1}$ were assigned to the $\gamma(\mathrm{SH})$ and $\delta(\mathrm{HSH})$ bands of the $\mathrm{H}_{2} \mathrm{~S}$ molecule on $\mathrm{Ag}-\mathrm{Y}$. The adsorbed TBT molecules react with silver ions in $\mathrm{Ag}(\mathrm{Na})-\mathrm{Y}(19)$ and decompose to hydrogen sulfide and $i$-butene ${ }^{15)}$.

The spectrum of $\mathrm{Cu}(\mathrm{Na})^{-} \mathrm{Y}(25)$ is shown in Fig. 6(c). The $\gamma(\mathrm{SH})$ peak observed at $2540 \mathrm{~cm}^{-1}$ and bands at $1465,1454,1370$, and $1360 \mathrm{~cm}^{-1}$ due to the $\delta(\mathrm{CH})$ of the $t$-butyl group of absorbed TBT were observed in the $\mathrm{CH}$ deformation region. These peaks are similar to the spectrum of TBT physically adsorbed on $\mathrm{Na}^{-} \mathrm{Y}$. Neither the absorption bands of $\gamma(\mathrm{SH})$ and $\delta(\mathrm{HSH})$ derived from $\mathrm{H}_{2} \mathrm{~S}$ nor the relatively sharp adsorption bands derived from $i$-butene which were observed in 


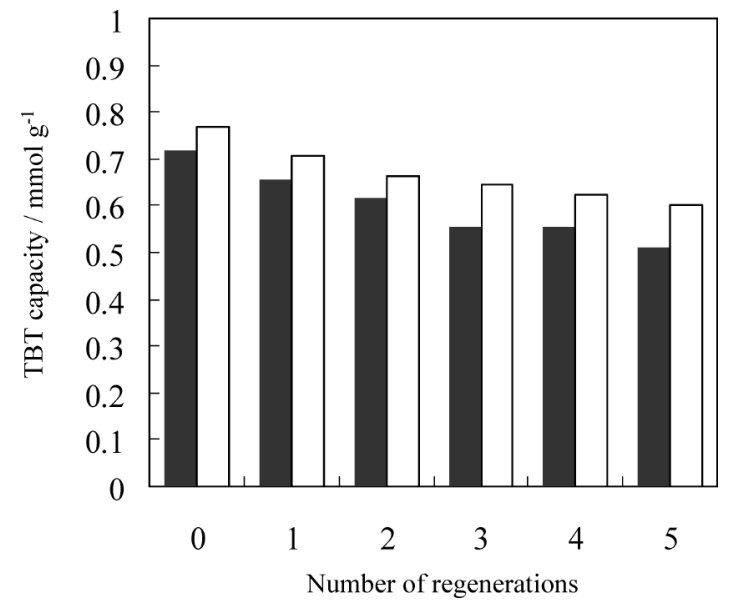

Fig. 7 Change in Adsorption Capacity of TBT on Fresh and the Regenerated Adsorbents; $\mathrm{Ag}(\mathrm{Na})-\mathrm{Y}(19)$ (solid line) and $\mathrm{Cu}(\mathrm{Na})-\mathrm{Y}(25)$ (open line)

Fig. 6(b) were observed in Fig. 6(c). Therefore, TBT is probably physically adsorbed on $\mathrm{Cu}(\mathrm{Na})-\mathrm{Y}(25)$ and decomposition of TBT molecules did not occur in the adsorption experiments on $\mathrm{Cu}(\mathrm{Na})-\mathrm{Y}(25)$.

\section{5. Regeneration}

All used $\mathrm{Ag}(\mathrm{Na})-\mathrm{Y}$ and $\mathrm{Cu}(\mathrm{Na})-\mathrm{Y}$ with color changes after the adsorption experiments were returned to the original color by regeneration treatment. The adsorption capacity of TBT on the regenerated $\mathrm{Ag}(\mathrm{Na})-\mathrm{Y}(19)$ or $\mathrm{Cu}(\mathrm{Na})-\mathrm{Y}(25)$ decreased slightly. Figure 7 compares the TBT adsorption capacities of fresh and regenerated $\mathrm{Ag}(\mathrm{Na})-\mathrm{Y}(19)$ and $\mathrm{Cu}(\mathrm{Na})-\mathrm{Y}(25)$ under the dry gas condition. The adsorption capacity of TBT decreased gradually with the number of regeneration cycles. The adsorption capacities of TBT on $\mathrm{Ag}(\mathrm{Na})$ $\mathrm{Y}(19)$ and $\mathrm{Cu}(\mathrm{Na})-\mathrm{Y}(25)$ regenerated five times were reduced to $28 \%$ and $21 \%$ compared with the fresh capacities, respectively. The decrease rate of TBT adsorption capacity on $\mathrm{Cu}(\mathrm{Na})-\mathrm{Y}(25)$ was lower than that on $\mathrm{Ag}(\mathrm{Na})-\mathrm{Y}(19)$.

\section{6. Affinities of Transition Metal Ions with TBT}

The HSAB (hard soft acid base) theory is widely used in chemistry for explaining the stability of compounds, reaction mechanisms and pathways. The terms (hard) or (soft), and (acid) or (base) are assigned to chemical species. Hard applies to species which are small with high charge states and are weakly polarized. Soft applies to species which are large with low charge states and are strongly polarized. According to the HSAB theory, silver ions and TBT molecules are classified as soft acid and soft base, respectively. Sodium ions and water molecules are classified as hard Lewis acid and hard Lewis base, respectively. Copper and zinc ions are classified as middle acids. The adsorption capacities of all adsorbents under the wet gas condition were increased by exchanging to transition metal ions instead of sodium ions in raw $\mathrm{Na}^{-} \mathrm{Y}$ zeolite because of the low interaction between metal ions and water molecules.

\section{Conclusions}

Sulfur adsorption capacities on silver, copper and zinc ions exchange $\mathrm{Y}$ type zeolites under the wet gas condition increased with higher ion-exchange ratio. However, in the case of silver ion, adsorption capacity under the dry gas condition decreased with higher ionexchange ratio. The decrease of sulfur adsorption capacity would be caused by the formation of $\mathrm{Ag}_{4} \mathrm{~S}_{2}$ clusters in $\mathrm{Ag}(\mathrm{Na})-\mathrm{Y}$ in the TBT adsorption experiment under the dry gas condition because of the strong interaction between TBT molecules and silver ions. Therefore, the highest sulfur adsorption capacity under both dry and wet gas conditions was achieved with $\mathrm{Cu}(\mathrm{Na})-\mathrm{Y}(25)$.

\section{References}

1) Farrauto, R., Hwang, S., Shore, L., Ruttinger, W., Lampert, J., Giroux, T., Liu, Y., Ilinich, O., Rev. Mater. Res., 33, 1 (2003).

2) Rostrup-Nielsen, J. R., "Catalysis Science and Technology," eds. by Anderson, J. N., Boudan, M., Vol. 5, Springer-Verlag, Berlin (1984), p. 95.

3) Topsøe, H., Clausen, B. S., Massoth, F. E., "Catalysis Science and Technology," eds. by Anderson, J. N., Boudan, M., Vol. 11, Springer-Verlag, Berlin (1996).

4) Futami, H., Hashizume, Y., Proc. 1989 International Gas Research Conference, 1990, p. 1592.

5) Wakita, H., Tachibana, Y., Hosaka, M., Micropor. Mesopor. Mater., 46, 237 (2001).

6) Satokawa, S., Kobayashi, Y., Fujiki, H., Stud. Surf. Sci. Catal., 145, 399 (2003).

7) Satokawa, S., Kobayashi, Y., Fujiki, H., Appl. Catal. B: Enviroment, 56, 51 (2005).

8) Kasaoka, S., Sasaoka, E., Funahara, M., Nihon Kagaku Kaishi, 1945 (1981).

9) Bezverkhyy, I., Bouguessa, K., Geantet, C., Vrinat, M., Appl. Catal. B: Enviroment, 62, 299 (2006).

10) Hernandez-Maldonado, A. J., Yang, R. T., J. Am. Chem. Soc., 126, 992 (2004).

11) Hernandez-Maldonado, A. J., Yang, R. T., Catal. Rev., 46, 111 (2004).

12) Yang, R. T., Hernandez-Maldonado, A. J., Yang, F. H., Science, 301, 79 (2003).

13) McKinley, S. G., Angelici, R. J., Chem. Commun., 2003, 2620.

14) Hayashi, A., Saimen, H., Watanabe, N., Kimura, H., Kobayashi, A., Nakayama, H., Tsuhako, M., Langmuir, 21, 7238 (2005).

15) Shimizu, K., Kobayashi, N., Satsuma, A., Kojima, T., Satokawa, S., J. Phys. Chem. B, 110, 22570 (2006).

16) Brühwiler, D., Seifert, R., Calzaferri, G., J. Phys. Chem. B, 103, 6397 (1999).

17) Garcia, C. L., Lercher, J. A., J. Phys. Chem., 95, 10729 (1991).

18) Ivanov, P., Papp, H., Langmuir, 16, 7769 (2000).

19) Kondo, J. N., Yoda, E., Ishikawa, H., Wakabayashi, F., Domen, K., J. Catal., 191, 275 (2000).

20) Trombetta, M., Busca, G., Rossini, S., Piccoli, V., Cornaro, U., J. Catal., 168, 349 (1997). 
要 旨

\title{
金属イオン交換 $\mathrm{Y}$ 型ゼオライトを用いたターシャリーブタンチオールの常温吸着除去
}

\author{
里川 重夫, 大貫 环郎, 高廣 智基, 浦崎 浩平, 小島 紀徳
}

成蹊大学理工学部物質生命理工学科, 180-8633 東京都武蔵野市吉祥寺北町3-3-1

\begin{abstract}
金属イオン交換 $\mathrm{Y}$ 型ゼオライトを用いて都市ガスに含まれ
卜は含水ガス条件では銅の導入量に従い TBT 吸着容量は増加 る付臭剤成分であるターシャリーブタンチオール（TBT）の常 温吸着除去を行った。乾燥ガス条件では市販の $\mathrm{Na}-\mathrm{Y}$ 型ゼオラ イトでも適度な TBT 吸着容量を示すが, 含水ガス条件では低 下した。銀イオン交換 $\mathrm{Y}$ 型ゼオライトは含水ガス条件で銀の し, 乾燥ガス条件では $\mathrm{Na}-\mathrm{Y}$ 型ゼオライトと同等の TBT 吸着 容量を示した。銅イオン交換 $\mathrm{Y}$ 型ゼオライトがいずれの条件 でも適度な性能を示すことが分かった。使用後のサンプルを空 気中で加熱処理すると再生できるが, 銀イオン交換 $\mathrm{Y}$ 型ゼオ 導入量に従い TBT 吸着容量は増加するが, 乾燥ガス条件では 銀の導入量に従い低下した。硫化銀クラスタの生成が性能低下 ライトより銅イオン交換 $\mathrm{Y}$ 型ゼオライトの方が性能低下割合 は小さかった。
\end{abstract}

を引き起こしていると思われた。銅イオン交換 $\mathrm{Y}$ 型ゼオライ 